\title{
MateriatY
}

Klio. Czasopismo poświęcone dziejom Polski i powszechnym PL ISSN 1643-8191, t. 43 (4)/2017, s. 135-147

\author{
(c) $(1) \Theta$ \\ http://dx.doi.org/10.12775/KLIO.2017.048 \\ Waldemar BuKoWsKi, JaN WronisZeWshi, \\ MACIEJ ZDANEK*
}

\section{Akta grodzkie i ziemskie z terenu dawnych województw krakouskiego i sandomierskiego. Edycja krytyczna ksiąg sądowych z XIV-XV wieku}

\author{
Castle and land records from the area of former Cracow \\ and Sandomierz Voivodships. Critical edition of court records \\ from the 14-15th centuries
}

Streszczenie: W ostatnich latach podejmowana jest dyskusja o sposobach edycji źródeł historycznych w epoce nowoczesnych technologii komputerowych, które obecnie pozwalają na elektroniczne zobrazowanie źródła i jego udostępnienie w Internecie. Pojawiają się

* W. Bukowski, Instytut Historii PAN, 31-016 Kraków, ul. Sławkowska 17; bukowski@ih.pan.krakow.pl; Jan Wroniszewski, Instytut Historii i Archiwistyki UMK w Toruniu, ul. Władysława Bojarskiego 1, 87-100 Toruń; jwr@umk.pl; Maciej Zdanek, Archiwum Uniwersytetu Jagiellońskiego, Aleja Adama Mickiewicza 22, 30-059 Kraków; maciej.zdanek@uj.edu.pl. Omawiany projekt jest realizowanyw ramach programu NPRH nr $11 \mathrm{H} 13022502$. 
w niej głosy, że dotychczasowe, krytyczne edycje papierowe powinny ustępować edycjom elektronicznym konkretnego źródła lub całych ich zespołów. Takie „edycje” zostałyby odpowiednio opracowane i zindeksowane. Autorzy uważają, że edycje krytyczne i edycje elektroniczne to dwa różne i równie potrzebne sposoby udostępniania źródła historycznego. Uważają jednak, że w przypadku źródeł średniowiecznych żadna edycja elektroniczna nie zastąpi tradycyjnej edycji krytycznej, w jakiejkolwiek formie (papierowej czy elektronicznej) ta ostatnia miałaby być zaprezentowana. Przedmiotem artykułu jest zatem wieloletni projekt krytycznej, tradycyjnej edycji najstarszych średniowiecznych ksiąg sądowych ziemskich i grodzkich z terenu dawnych województw krakowskiego i sandomierskiego. Zespół tych ksiąg liczy około 100 jednostek archiwalnych. Dotychczas opublikowano w XIX w. część ksiąg z lat 1374-1400 oraz obszerny wybór z ksiąg piętnastowiecznych. W 2012 roku autorzy opublikowali jedną księgę z lat 1394-1397. Obecnie planowana jest publikacja kilkunastu kolejnych ksiąg z lat 1394-1430. Projekt jest finansowany przez Ministerstwo Nauki w ramach Narodowego Programu Rozwoju Humanistyki.

Abstract: Recent years saw many discussions on edition of historical sources in era of modern IT technologies that provide possibilities for digitalization of the source and publishing it in Internet. There are several opinions that traditional, critical paper editions should be replaced with digital editions of a specific source or groups of them. Such "editions" would be prepared in special manner and indexed. Authors argue, that the critical and digital editions are two different and both needed ways of publishing historical sources. They state, however, that in case of the mediaeval sources a digital edition of any type would not be able to replace a traditional, critical edition, with no difference to its form of presentation (paper or digital). Authors present a long-standing project of preparing critical, traditional edition of the earliest mediaeval castle and land court records from the area of former Cracow and Sandomierz Voivodships. The collection of these judiciary books includes c. 100 archival units. A part of them from the years 1374-1400 was published in the 19th century, while the 20th-21st centuries saw printed editions of a large selection from the content of the 15th century records. In 2012 the authors published one book from the years 1394-1397. Edition of several other books from the years 1394-1430 is being prepared at the moment as a part of the project financed by Polish Ministry of Science, the National Programme for the Development of Humanities.

Słowa kluczowe: edycje źródeł; księgi sądowe ziemskie i grodzkie; średniowiecze; Małopolska; Kraków; Sandomierz

Keywords: editions of historical sources; castle and land judicial records; Lesser Poland; Cracow; Sandomierz 
erie wydawnicze określonego typu źródeł, zwłaszcza o charakterze „ma-
sowym”, zazwyczaj rozciagaja się w czasie. Niektóre, podjęte ponad 100 lat temu, nadal pozostają nieukończone. Ze względu na rozmiar zadania bywały one zawieszane, przede wszystkim wskutek przerwania ciagłości pokoleniowej wydawców. Inną przyczyną były postępujące zmiany paradygmatów określających zasadnicze potrzeby edytorskie. Wydaje się, że w obecnej chwili, gdy w wyniku zakwestionowania niewzruszalnego zdawało się paradygmatu, jakim była potrzeba i sposoby krytycznej edycji źródeł, zakwestionowania wynikającego z przemyśleń czysto merytorycznych ${ }^{1}$, jak również z rozwoju nowoczesnych technologii, pozwalających obecnie na zobrazowanie elektroniczne źródła i jego udostępnienie w Internecie, musimy spokojnie zastanowić się, jak wydawać i udostępniać źródła badaczom $^{2}$. Celowo używamy tu tego rozróżnienia, gdyż naszym zdaniem są to dwa różne i równie potrzebne sposoby udostępniania źródła historycznego, zaś wybór jednego z nich zależy od kategorii źródła oraz potrzeby i możliwości sfinalizowania edycji, zwłaszcza gdy obejmuje ona materiał masowy, jak np. księgi sądowe. Nie wchodząc w polemikę z podważaniem celowości klasycznego (krytycznego) wydawania źródeł, uważamy za Arystotelesem, że scienciae funt per additamenta. Każda zatem publikacja źródłowa przynosi historykom kolejną porcję wiedzy, dzięki której lepiej może on zrozumieć dawną rzeczywistość.

W niniejszym tekście chcemy przedstawić realizowany obecnie projekt edycji krytycznej najdawniejszych ksiąg sądowych krakowskich z końca XIV i początku XV wieku oraz obszerny wybór zapisek z całego XV wieku. Wpisuje się on w obydwa zarysowane we wstępie zagadnienia. $Z$ jednej

${ }^{1}$ J. S. Matuszewski, Nowe wydawnictwo źródtowe do dziejów Wielkopolski. Uwagi $w$ zwiąku z tomem VI Kodeksu dyplomatycznego Wielkopolski, „Czasopismo PrawnoHistoryczne" (1985), 37, z. 2, s. 327-337; A. Gąsiorowski, O metodzie wydawania średniowiecznych dokumentów, „Czasopismo Prawno-Historyczne” (1986), 38, z. 1, s. 199-206; J. S. Matuszewski, Historyk, źródto i ... komputer (na marginesie edycji Księgi ziemskiej kaliskiej), „Kwartalnik Historyczny” (1993), 100, nr 2, s. 27-36.

${ }_{2}$ Zob. np. rozważania Marka Słonia, recenzja z książki: J. Tandecki, Edytorstwo źródet historycznych, Warszawa 2014, w: „Studia Źródłoznawcze” (2014), 52, s. 181-183; , Pryncypia edytorstwa źródet historycznych $w$ dobie rewolucji cyfrowej, „Studia Źródłoznawcze” (2015), 53, s. 155-161. 
strony ma być dokończeniem i kontynuacją dotychczasowych wydawnictw, z drugiej zaś będzie to edycja krytyczna³.

Projekt jest zaplanowanym na kilkanaście lat programem, jakim ma być krytyczna edycja najstarszych krakowskich ksiąg sądowych grodzkich, ziemskich, wiecowych i nadwornych do roku co najmniej 1430. Ta nowa kategoria źródeł, pojawiająca się od 1374 roku i to od razu w skali masowej, obejmująca księgi różnych kategorii sądów, rejestrujących codzienną aktywność wszystkich warstw społeczeństwa oraz mniej więcej jednolitych pod względem formularza i kategoryzacji spraw, daje historykom do ręki cenne narzędzie badawcze, które może być wykorzystane zarówno do ujęć socjologicznych, jak i kwantytatywnych. Nie ma zatem potrzeby uzasadniać takich przedsięwzięć edytorskich ${ }^{4}$, dyskusji może co najwyżej podlegać sposób i zakres chronologiczny edycji.

Przechowywany w Archiwum Narodowym w Krakowie, Oddział na Wawelu zespół ksiąg sądowych ziemskich i grodzkich liczy 3,5 tys. ksiąg z lat 1374-1796. Stanowi największy i najbardziej kompletny zespół źródeł tego typu w Polsce, obok podobnych lub nawet bardziej licznych zespołów ksiąg ziem ruskich i ukrainnych dawnej Rzeczypospolitej, przechowywanych dziś poza granicami Polski, we Lwowie (od XV wieku) i w Kijowie (od XVI wieku). Z okresu średniowiecza znajduje się tam $101 \mathrm{ksiąg} \mathrm{sądowych}$ grodzkich i ziemskich z powiatów dawnego województwa krakowskiego oraz 11 ksiąg ziemskich powiatu pilzneńskiego dawnego województwa sandomierskiego. Są to jedyne zachowane po II wojnie księgi sandomierskie, ponieważ księgi pozostałych powiatów znalazły się w Archiwum Głównym w Warszawie i podzieliły los innych akt, spalonych przez Niemców podczas niszczenia polskich dóbr kultury po upadku Powstania Warszawskiego w 1944 roku.

${ }^{3}$ Wykaz opublikowanych zapisek krakowskich i sandomierskich zob. K. Piekarski, Przeglad wydawnictw średniowiecznych zapisek i rot sadowych z ksiag grodzkich i ziemskich, Kraków 1919, s. 72-94. Autor porządkuje publikacje nie według tytułów wydawnictw, lecz według ówczesnych sygnatur ksiąg.

${ }^{4}$ Podsumowanie dyskusji na ten temat zob. wstęp do: Księga ziemska krakowska 2: 1394, wyd. W. Bukowski i M. Zdanek, (Pomniki prawa polskiego, dział I: Prawo ziemskie, t. 3), Warszawa 2012, s. 21-26. 
Najstarsze zachowane księgi ziemskie krakowskie zaczynają się w $1374 \mathrm{roku}^{5}$. Z okresu średniowiecza pochodzą 73 księgi ziemskie, w tym:

-27 powiatowych krakowskich (Terr.Crac. 1, 1a, 1b, 1c, 2, 2a, 2b, 3, 3a, 3b, 4-21),

- 12 proszowskich (Terr.Crac. 193-204),

- 9 ksiąskich (Terr.Crac. 256-264),

- 7 lelowskich (Ter.Crac. 311-316, 319),

- 5 bieckich (Terr.Biec. 1a, 1-4),

- 7 czchowskich (Terr.Czchov. 1-7),

- 2 księgi wiecowe (Terr.Crac. 146-147),

- 4 księgi sądu nadwornego (Terr.Crac. 150-153),

Ponadto znajduje się tam 29 ksiąg grodzkich krakowskich, w tym:

- 29 grodzkich krakowskich (Castr.Crac. 1a, 1b, 1-27),

- 2 grodzkie bieckie (Castr.Biec. 4-5),

- 3 księgi sądu wyższego prawa niemieckiego w Bieczu (GB 1-3), z których najstarsza pochodzi z lat 1378-1404, a wszystkie zostały zakwalifikowane błędnie jako grodzkie bieckie.

Ze względu na zachowanie niemal w komplecie zespołu aktowego sądów województwa krakowskiego, w tym ksiąg o szerszym zasięgu, jak księgi wiecowe i nadworne, udostępnienie ich historykom w jak najszerszym zakresie i w jak najbardziej przyjaznej formie jest zadaniem pierwszorzędnym. Problemem w korzystaniu z ksiąg jest ich duża liczba, ograniczona dostępność treści ze względu na trudności paleograficzne, kodykologiczne (zwłaszcza błędne zszywki składek utrudniające odtworzenie chronologii wpisów), a także trudności warsztatowe związane z koniecznością ogarnięcia, uprządkowania, przeszukania i poprawnej interpretacji interesującego historyka materiału zapiskowego. $\mathrm{Z}$ tych m.in. powodów księgi sądowe są ciągle w ograniczonym zakresie wykorzystywane w badaniach mediewistycznych. Pilnym postulatem jest więc jak najszersze udostępnienie za-

5 Szczegółowy wykaz ksiąg z okresu średniowiecza zob. W. Bukowski, M. Zdanek, Über die Notwendigkeit und Methode der Herausgabe der Krakauer Landgerichtsbücher. Randbemerkungen zur Vorbereitung des Krakauer Landgerichtsbuchs 2 aus dem Jahren 1394 -1397, [w:] Editionswissenschaftliches Kollquium 2011: Quellen Kirchlicher Provenienz neue Editionsvorhaben und Aktuelle EDV-Projekte, hrsg. von H. Flachenecker und J. Tandecki unter mitarbeit von Krzysztof Kopiński, Toruń 2011, s. 316-332. 
wartości ksiąg sądowych na dwa sposoby: poprzez ogólnodostępne skany oryginałów (już realizowane przez niektóre archiwa, acz nazbyt opieszale) i krytyczne edycje drukowane (bądź zamieszczane w Internecie), zaopatrzone we wstępy, aparat tekstowy, a przede wszystkim nowoczesne indeksy. Tym bowiem, co nadaje sens edycjom krytycznym, obok uprzystępnienia badaczom poprawnego tekstu, są indeksy porządkujące materiał, identyfikujące osoby i miejscowości. Bez nich obszerne wydawnictwa materiału zapiskowego nie uzyskują należnej im wartości, gdyż pozostają chaotyczną zbieraniną zapisek, w której nie sposób odnaleźć potrzebne informacje. Brak zapowiedzianych, ale nigdy nie opracowanych indeksów osobowo-geograficznych w klasycznych, wspomnianych wyżej wydawnictwach Helcla i Ulanowskiego znacznie obniżył stopień wyzyskania badawczego tych fundamentalnych edycji.

Niniejszy projekt ma na celu rozpoczęcie długofalowego programu udostępnienia polskiej mediewistyce w jak najszerszym zakresie bogactwa materiału źródłowego, zawartego w księgach sądowych ziemskich i grodzkich historycznej Małopolski. Projekt nawiązuje do trzech największych dotąd przedsięwzięć w tym zakresie, wyrosłych z przekonania naszych dziewiętnastowiecznych poprzedników, że publikacja źródeł pomnaża liczbę jego użytkowników, daje fundament pod rozwój nowoczesnych badań, chroni treść źródła przed zniszczeniem, a tym samym stanowi konieczny element ochrony i promocji historycznego dorobku kultury narodowej.

Pierwszy $\mathrm{z}$ nich to wydawnictwo Antoniego Zygmunta Helcla z 1856 roku pt. „Starodawne prawa polskiego pomniki”, w którym zamieścił rozdział pt. „Sądowa praktyka prawa przy końcu XIV wieku”, a w jego ramach opublikował wybór 435 najstarszych zapisek krakowskich z lat 1388-13906. W 1870 roku Helcel wydał drugi tom wspomnianego wydawnictwa, którego zasadniczą część zatytułował „Wyciągi z najdawniej-

${ }^{6}$ Sadowa praktyka prawa przy końcu XIV wieku. Wyimki z najdawniejszych ksiag sadowych ziemi krakowskiej, mianowicie z lat 1388, 1389 i 1390, [w:] Starodawne prawa polskiego pomniki, t. 1, wyd. A. Z. Helcel, Warszawa-Kraków 1856, s. 227-262. 
szych ksiąg sądowych ziemi krakowskiej”. Opublikował w niej 4568 zapisek z lat 1394-1507 z ksiąg krakowskich i bieckich

W latach 1884-1886, jako ósmy tom ww. serii, ukazało się w dwóch woluminach monumentalne wydawnictwo Bolesława Ulanowskiego ${ }^{8}$. Wydał on najstarszy znany mu zasób krakowskich ksiąg ziemskich do 1400 roku (TerrCrac. 1, 1a, 1b, 2a, 2b, fragment 3), ale bez dwóch ksiag: TerrCrac. 1c i 2, które przechowywano pod błędnymi sygnaturami w Archiwum Głównym w Warszawie. Już wcześniej, jako siódmy tom „Starodawnych prawa polskiego pomników”, Ulanowski opublikował 1572 zapiski herbowe z różnych ksiąg krakowskich z lat 1382-1506?.

Mniej więcej w tym samym czasie, w latach 1886-1906, środowisko historyków lwowskich realizowało największe i, jak dotąd, najbardziej ambitne przedsięwzięcie edytorskie $\mathrm{w}$ polskiej historiografii $\mathrm{w}$ zakresie edycji masowego materiału zapiskowego z okresu późnego średniowiecza. Były to „Akta grodzkie i ziemskie”. W ramach tej serii wydano dziewięć tomów zapisek ze wszystkich ksiąg sądowych dawnego województwa ruskiego ${ }^{10}$. Edycję pojedynczych ksiąg podejmowali historycy w innych ośrodkach, publikując najstarsze dla poszczególnych dzielnic: Jan Tadeusz Lubomirski (1879, księgi mazowieckie), Józef Lekszycki (1887-1889, księgi wielkopolskie), Adolf Pawiński (1897-1898, księgi łęczyckie), Jan Karol Kochanowski (1905, księgi brzeskie kujawskie), Handelsman, Rybarski, Tymieniecki (1920, księgi mazowieckie), żeby wymienić tylko najważniejsze ${ }^{11} . \mathrm{Z}$ nieco

7 Starodawne prawa polskiego pomniki z ksiag rękopiśmiennych dotąd nieużytych, gtówniej zaś z ksiag sądowych ziemskich i grodzkich ziemi krakowskiej, wyd. A. Z. Helcel, (Starodawne prawa polskiego pomniki, t.2), Kraków 1870.

${ }^{8}$ Antiquissimi libri iudiciales terrae Cracoviensis. Najdawniejsze ksiegi sadowe krakowskie, P. 1: 1374-1390; P. 2: 1394-1400, ed. B. Ulanowski (Starodawne prawa polskiego pomniki, t. 8, cz. 1-2) Cracoviae 1884-1886.

${ }^{9}$ Inscriptiones clenodiales ex libris iudicialibus palatinatus Cracoviensis, ed. B. Ulanowski, [w:] Starodawne prawa polskiego pomniki, t. 7 [z. 3], Cracoviae 1885, s. 277-626.

${ }^{10}$ Akta grodzkie $i$ ziemskie z czasów Rzeczypospolitej Polskie z Archiwum tzw. Bernardyńskiego 2e Lwowie, t. 11-19, wyd. O. Pietruski, X. Liske, A. Prochaska, Lwów 1868-1906.

${ }^{11}$ Księgi ziemi czerskiej 1404-1425, wyd. J. T. Lubomirski, Warszawa 1879; Die ältesten Grosspolonischen Grodbücher, t. 1-2, wyd. J. von Lekszycki, Posen 1887-1889; Księgi sądowe tęczyckie 1385-1419, t. 1-2, wyd. A. Pawiński, (Teki Pawińskiego 3-5), Warszawa 
skromniejszego zasobu ksiąg sandomierskich jedynie niewielki wybór najstarszych zapisek wydał w 1907 roku Franciszek Piekosiński ${ }^{12}$.

Po I wojnie światowej edycje ksiąg zostały wprawdzie wyhamowane, nie zaprzestano jednak prac indywidualnych. Jeśli idzie o księgi krakowskie, to w latach 1929-1939 Franciszek Duda, dyrektor Archiwum Aktów Grodzkich i Ziemskich i Archiwum Państwowego, przygotował uzupełnienie edycji Helcla. Sporządził wybór 14376 zapisek z ksiąg sądowych krakowskich, bieckich, pilzneńskich i zaginionej dziś księgi zatorskiej 2a (1476-1528), skradzionej z archiwum w czasie II wojny przez niemieckiego żołnierza ze względu na piękną, skórzaną oprawę. Zapiski zajęły 3,6 tys. kart rękopisu i maszynopisu in folio. Na jednej z kart, stanowiących okładkę do nigdy nie napisanego wstępu, zanotował pod datą 29 września 1939 roku: „Przygotowane do druku”. Nie jest to zgodne z prawda, ponieważ maszynopis, a częściowo rękopis, upstrzony jest odręcznymi dopiskami i poprawkami i jego przygotowanie do druku wymaga jeszcze wiele pracy, głównie skolacjonowania odpisów z rękopisami13. Podejmowane po wojnie próby edycji się nie powiodły.

Nie wyszła drukiem przygotowywana w dwudziestoleciu międzywojennym przez Abdona Kłodzińskiego i niedoprowadzona do końca, przerwana jego nagłą śmiercią w 1937 roku, edycja najstarszej księgi sądu prawa niemieckiego na zamku bieckim z lat 1378-1404, zakwalifikowanej błędnie do zespołu ksiąg bieckich grodzkich pod sygnaturą Castr.Biec. 1. (ta cenna księga przewidziana jest do publikacji w następnej kolejności).

Po II wojnie podjęto liczne prace edytorskie. Dotyczyło to także źródeł średniowiecznych. W 1952 roku Komitet Nauk Prawnych PAN utworzył

1897-1898; Ksiegi sadowe brzesko-kujawskie 1418-1424, wyd. J. K. Kochanowski, (Teki Pawińskiego 7), Warszawa 1905; Najdawniejsze ksiegi sadowe mazowiecki, t. 1: Księga ziemska ptońska 1400-1417, wyd. M. Handelsman; t. 2: Księga ziemska zakroczymska pierwsza 1423-1427, wyd. A. Rybarski; t. 3: Księga ziemska zakroczymska druga 1434-1437, wyd. K. Tymieniecki, Warszawa 1920.

${ }_{12}$ Zapiski sądowe województwa sandomierskiego 1395-1444, wyd. F. Piekosiński, [w:] Archiwum Komisji Prawniczej, t. 8, Kraków 1907, s. 61-175.

${ }_{13}$ Wybrane zapiski z ksiagg grodzkich i ziemskich województwa krakowskiego z lat 1401-1506, maszynopis w posiadaniu Archiwum Narodowego w Krakowie, Oddział I na Wawelu, nr 1572, sygn. F 12. 
Komisję Redakcyjną Wydawnictw Źródłowych pod kierunkiem Adama Vetulaniego. Powstała nowa seria wydawnicza „Pomniki Prawa Polskiego”, która miała kontynuować tradycję serii „Starodawne Prawa Polskiego Pomniki” Polskiej Akademii Umiejętności. W 1953 roku zadecydowano, że oprócz pomników ustawodawstwa ziemskiego i miejskiego w ramach nowej serii będą wydawane również księgi sądowe wiejskie i ziemskie. Jednak zapewne z powodów ideologicznych skupiono się na edycji ksiąg sądowych wiejskich (skopiowano wówczas około 100 ksiąg wiejskich od XV do XVIII wieku, dziś są one przechowywane w Instytucie Historyczno-Prawnym UJ).

Do idei wydawania ksiąg ziemskich powrócił w 1956 roku Jan Adamus. Poparł go Adam Wolff, wydawca „Metryki mazowieckiej” i „Mazowieckich zapisków herbowych”, orędownik edycji zachowanych ksiąg ziemskich mazowieckich. Uważał on, słusznie, że wydawanie pojedynczych ksiąg, obejmujących najczęściej kilka lat działalności sądu, nie może dać efektów badawczych ze względu na specyfikę materiału zapiskowego. $\mathrm{Na}$ posiedzeniu w 1957 roku omawiano nawet przygotowany przez Wolffa projekt wydawnictw ksiąg sądowych ziemskich. Nie został on jednak opublikowany, ale należałoby go odszukać. W ramach serii, do momentu jej zawieszenia w drugiej połowie lat siedemdziesiątych XX wieku, nie wydano ostatecznie żadnej księgi. Poza serią opublikowano księgę ziemską poznańską $^{14}$ i kaliską ${ }^{15}$ oraz duży zbiór wielkopolskich rot sądowych ${ }^{16}$. Seria „Pomniki Prawa Polskiego” została odnowiona w 2012 roku, kiedy to w jej ramach wydano księgę ziemską krakowską TerrCrac. 2 z lat 1394-139717. Podobnie jak TerrCrac. 1c, nie weszła ona do wydawnictwa Ulanowskiego, gdyż nie była mu znana.

Podczas prac nad tą księgą wydawcy wypracowali podstawy metodologiczne i organizacyjne długofalowego programu edytorskiego. Jego istotą jest sukcesywne przygotowanie krytycznych edycji kolejnych naj-

${ }^{14}$ Księga ziemska poznańska 1400-1407, wyd. K. Kaczmarczyk, K. Rzyski, Poznań 1960.

15 Ksiegga ziemska kaliska 1400-1409, wyd. T. Jurek, Poznań 1991.

16 Wielkopolskie roty sądowe XIV-XV wieku, t. 1-5, wyd. H. Kowalewicz, W. Kuraszkiewicz, Wrocław 1959-1981.

17 Zob. przyp. 2. 
starszych ksiąg sądowych ziemskich i grodzkich krakowskich. Równorzędnym elementem planu jest udostępnienie badaczom wspomnianych wyżej niedokończonych i nieogłoszonych drukiem wypisów Franciszka Dudy w czterech obszernych tomach. Odrębny tom będzie zawierał indeksy osobowo-geograficzne do wydawnictw Helcla i Dudy, które wreszcie umożliwią operowanie tym gigantycznym materiałem zapiskowym i pozwolą mu w pełni zaistnieć $\mathrm{w}$ warsztatach badawczych mediewistów.

Tytuł projektu, anonsowany w tytule niniejszego wystąpienia, celowo nawiązuje do monumentalnego wydawnictwa średniowiecznych ksiąg sądowych dawnego województwa ruskiego pt. „Akta grodzkie i ziemskie z czasów dawnej Rzeczypospolitej z archiwum tzw. bernardyńskiego we Lwowie", zrealizowanego w ciągu 20 lat pod patronatem i z fundacji hr. Aleksandra Stadnickiego, gdyż w pewnym stopniu odpowiada duchowi tamtego przedsięwzięcia. Krakowskie wydawnictwo ma ambicję przynajmniej częściowo mu dorównać, chociaż nie planuje się z nim mierzyć, jeśli idzie o skalę, choćby z tego powodu, że ksiąg małopolskich jest ponaddwukrotnie więcej, a i umiejętności edytorskie oraz odpowiedni poziom znajomości łaciny i paleografii są dziś wśród badaczy raczej wyjątkiem niż codzienną praktyką.

Przedmiotem projektu jest najstarszy zespół tych ksiag do roku 1436, a więc do momentu zakończenia procesu specjalizacji i wyodrębnienia rodzajów sądów. Księgi te początkowo miały charakter ogólny, tzn. na każdej składce w jednej księdze wpisywano sprawy niezależnie od miejsca odbywania roczków w danym powiecie. System oddzielnych ksiąg dla każdego powiatu zaczęto zaprowadzać od końca XIV wieku: dla powiatu krakowskiego od 1397, dla czchowskiego od 1399, dla lelowskiego od 1406, dla proszowskiego wraz z ksiąskim od 1409, bieckiego od 1411, a w 1437 roku wydzielono z ksiąg proszowskich księgi dla powiatu ksiąskiego. Jeszcze później założono osobne serie ksiąg dla poszczególnych rodzajów sądów. Od 1425 roku zaprowadzono osobne księgi wiecowe, a od 1436 roku osobne księgi nadworne.

Przewidziane w obecnym projekcie zadania skupiają się w dwóch modułach:

1) Krytyczna edycja najstarszych niewydanych ksiąg ziemskich i grodzkich krakowskich: 
a) TerrCrac. 1c (1389-1398); zawiera wpisy roczków powiatowych krakowskich, proszowskich, lelowskich i ksiąskich oraz sądów wiecowych i nadwornych;

b) TerrCrac. 3 (1399-1403); zawiera wpisy roczków powiatowych krakowskich oraz sądów wiecowych i nadwornych;

c) CastrCrac. 1a (1407-1409); jedna z najstarszych ksiąg sądu grodzkiego krakowskiego, zachowana $\mathrm{w}$ oryginale, do 1948 roku przechowywana w AGAD jako księga rachunków królewskich nr 5;

d) CastrCrac. 1b (1406-1407); zachowana jedynie w odpisie dziewiętnastowiecznym najstarsza księga grodzka krakowska, przechowywana w AN w Krakowie (sygn. Zespół 1571: Spuścizna Franciszka Piekosińskiego, F 28). Jej oryginał przechowywany był do II wojny w AGAD jako księga asesorska 348, uległ zniszczeniu w 1944 roku.

Zasady pracy nad tekstem będą prowadzone według metodyki wypracowanej w trakcie pracy nad wydaną w 2012 roku księgą ziemską krakowską drugą, na podstawie krytycznego omówienia dotychczasowych stanowisk oraz doświadczeń badawczych prawno-historycznych i historycznych szkół edytorskich, instrukcji wydawniczych oraz praktyki prac archiwalno-badawczych nad zespołem ksiąg sądowych krakowskich. Każda wydawana księga sądowa zostanie opracowana i wydana jako odrębna, oryginalna jednostka archiwalna. Zadaniem wydawców będzie dokonanie opisu kodykologicznego każdej z ksiąg (rozpoznanie oprawy, układ składek i kart oraz ewentualne ich uporządkowanie według porządku chronologicznego, rodzaje rąk pisarskich), analiza zawartości, odczyt i transkrypcja tekstu łacińskiego zgodnie z przyjętymi zasadami wydawniczymi (oddanie skreśleń, razur, poprawek i dopisek, zastosowanie przyjętego w edycjach ujednolicenia ortografii i modernizacji pisowni), konieczne rekonstrukcje tekstu, rozwiązanie skrótów pisarskich i datacji, opracowanie krytycznego aparatu tekstowego w przypisach, nadanie jednolitej numeracji zapisek w obrębie księgi, sporządzenie wstępów historycznych, źródłoznawczych i edytorskich dla każdej księgi oraz indeksów osobowo-geograficznych identyfikujących występujące osoby, miejscowości i obiekty topograficzne. Wyjątkowo dla księgi Castr.Crac. 1b podstawą wydawniczą - z powodu nieistnienia oryginału - będzie odpis. Wadliwość odpisu, sporządzonego przez dwóch kopi- 
stów według niejednolitych zasad odwzorowania kopiowanego tekstu, wymaga studium maniery pisarskiej kopistów poprzez porównanie oryginału i analogicznej kopii księgi Castr. Crac. 1a.

2) Krytyczna edycja zapisek przygotowanych przez Franciszka Dudę z lat 1401-1506 (AN w Krakowie, zespół nr 1572: Spuścizna Franciszka Piekosińskiego, sygn. F 12).

Całość liczy około 3,6 tys. stron rękopisu i maszynopisu. Pojedyncze karty znajdują się też w Bibliotece PAN i PAU w Krakowie w spuściźnie F. Dudy. Odpisy zostały pomyślane przez autora jako wybór uzupełniający wydawnictwo Antoniego Z. Helcla. Stąd sporo jest zapisek kontynuujących lub poprzedzających pojedyncze sprawy publikowane przez Helcla prawnika, przez co historyk Duda nadaje im szerszy kontekst. Duda wykonał swoją pracę w latach 1929-1939, wybierając materiał z następujących ksiąg:

- księgi ziemskie krakowskie, sygn. TerrCrac. 3a, 3b, 4-23, 146-147, 150-154, 193-204, 256-264, 311-316, 319, 416a, 416b (łącznie 58 ksią);

- księgi ziemskie czchowskie, sygn. 1-5, 5a, 7 (łącznie 7 ksiąg);

- księgi ziemskie bieckie, sygn. 1, 1a, 2-4 (łącznie 5 ksiąg);

- księgi grodzkie krakowskie, sygn. 1-29;

- księgi ziemskie pilzneńskie, sygn. 1-3, 18, 20, 21 (łącznie 6 ksiąg).

Jest to więc szerszy zakres terytorialny niż u Helcla. Zamiar autorski objął wybór zapisek o szczególnym znaczeniu prawno-historycznym (przewód sądowy, kary, retrakt, terminologia prawna), do dziejów dawnych podziałów administracyjnych, urzędów publicznych, dostojników, królewszczyzn, spraw granicznych, cen, kmieci, wójtów, sołtysów i włodarzy, ważniejszych instytucji społeczno-kulturalnych (szkoły, Uniwersytet Krakowski, szpitale, kościoły). Autor nadał zapiskom, podobnie jak Helcel, układ chronologiczny w obrębie poszczególnych ciągów ksiąg: osobno ziemskich i grodzkich krakowskich, osobno ziemskich i grodzkich czchowskich i osobno bieckich. Zapiskom zostanie być może nadana ciągła numeracja (ale to zależy od możliwości sfinansowania druku kilku tomów naraz), umowne skróty zostaną rozwiązane, dodany ewentualny konieczny aparat tekstowy lub rzeczowy oraz konkordancja numerów zapisek i odpowiadających im numerów ksiąg i stron, ponieważ numeracja wielu ksiąg została 
zmieniona. Materiał zajmie co najmniej cztery obszerne tomy o łącznej objętości ok. 170 arkuszy. Całość opatrzona zostanie indeksem opublikowanym w osobnym tomie, który zawierać będzie także indeks do wydawnictwa Helcla. Wydawnictwo nosi tytuł roboczy: „Wybrane zapiski z ksiąg sądowych grodzkich i ziemskich województwa krakowskiego i sandomierskiego z lat 1401-1510".

Wybrane do edycji najstarsze księgi krakowskie posiadają lub będą wkrótce posiadać profesjonalne skany, które można odszukać na stronach Małopolskiej Biblioteki Cyfrowej, choć nie działa ona sprawnie. Krytyczna edycja w połączeniu z obrazem powinna zatem nadać temu przedsięwzięciu nową jakość. 